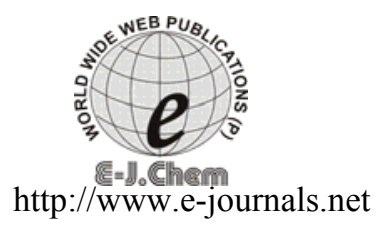

ISSN: 0973-4945; CODEN ECJHAO

E-Journal of Chemistry

2011, 8(S1), S474-S480

\title{
Sodicity and Salinity Hazards in Water Flow Processes in the Soil
}

\author{
R. P. DHOK ${ }^{\# *}$ A.S. PATIL ${ }^{\S}$ and V.S. GHOLE ${ }^{\#}$ \\ "Department of Environmental Science \\ University of Pune (Maharashtra), India \\ ${ }^{\S}$ Department of Plant Pathology \& Agri. Microbiology, V.S. I. Manjari, Pune \\ \& Agri Biotechnology, VSBT, Baramati, (Maharashtra), India \\ \#Department of Environmental Science, University of Pune \& \\ \#Department of Environmental Science, V. S. I. Manjari, Pune (Maharashtra), India \\ dhokrp@gmail.com
}

Received 23 February 2011; Accepted 26 April 2011

\begin{abstract}
Groundwater is one of the natural resource with the potential for domestic, agricultural and industrial consumption. This paper presents the results of the distribution of salinity characteristics (electrical conductivity and sodium adsorption ratio) of groundwater and based on the results, the evaluation of the sodicity and salinity hazards or in the processes if such groundwater is used for such purposes has been restrictive. This is because of the salinization of aquifers generated by rock salt present below the aquifers. The issue was studied for the groundwater environment in the Karha river basin area, Baramati, Pune, (M.S.) India, for the period of September 2009 to August 2010. The measured data were presented in the form of graphical attachments. The average annual values of the electrical conductivity of groundwater ranged from 490 to $8920 \mu \mathrm{S} / \mathrm{cm}$ in the examined period. Data obtained from analysis signifies the salinity of groundwater in study area is high to very high salinity and can't be used for crops in a soil with restricted drainage but it can be used under very special circumstances. The sodium adsorption ratio values indicate low, medium to high sodium salinization of the groundwater.
\end{abstract}

Keywords: Groundwater, Electrical conductivity, Sodium adsorption ratio, Salinity hazard, Sodicity hazard

\section{Introduction}

Water is a valuable resource on which all life is dependent. Water is a basic necessity of life, not only for people but for every type of plant and animal as well ${ }^{1}$. 
The present study aims at the assessment of sodicity and salinity hazard of groundwater of drought prone Karha river basin area, Baramati, Pune, (Maharashtra), India. Leaching of rock is a natural process and ion concentration in soil and water becomes higher, such groundwater when used for irrigation it leads to the accumulation of salts in the soil profile ${ }^{2}$. Groundwater is drawn by evapotranspiration, and soluble salts coagulate on the surface of soil particles and sodium ions are adsorbed into the soil colloidal system $^{3}$ (Figure 1).

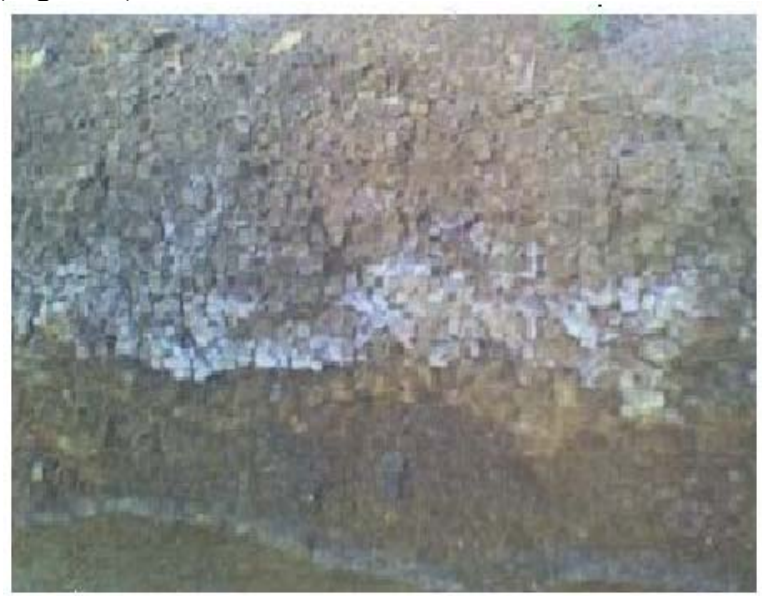

Figure 1. Soil surface contaminated with excess of salts

When such water is used for agricultural purposes, the suitability of water depends on how it can be used under specific conditions. These conditions include the tolerance of crops to salts, various physical and chemical properties of soil, management of irrigation methods and climatic conditions in the given region ${ }^{7}$.

The total water mineralization is defined as the sum of mass concentrations of solid inorganic substances dissolved in water, electrolytes (cations and anions) and nonelectrolytes. The term salinity relates to the total concentration of the main dissolved inorganic ions, i.e. $\mathrm{Na}^{+}, \mathrm{K}^{+}, \mathrm{Ca}^{2+}, \mathrm{Mg}^{2+}, \mathrm{HCO}^{3-}, \mathrm{SO}_{4}{ }^{2-}$ and $\mathrm{Cl}^{-}$in groundwater ${ }^{4}$. The total concentration of salts (i.e. the salinity) is expressed as the sum of the individual cations and anions in $\mathrm{mmol} / \mathrm{L}$, or in $\mathrm{mg} / \mathrm{L}$. For reasons of analytical simplification the real salinity indicator is the electrical conductivity of water (EC) expressed in $\mu \mathrm{S} / \mathrm{cm}$. Electrical conductivity is always expressed at a standard temperature of $25^{\circ} \mathrm{C}$ in order to allow for the comparison of electrical conductivity in various climatic conditions. The adverse effect of irrigation water quality on the physical properties of soil is associated with the accumulation of sodium ion on the soil exchange complex which imparts instability to the soil aggregates and whose disruption is followed by dispersion of clay particles resulting in clogging of soil pores $^{5-9}$.

The objective of the present paper was to obtain groundwater salinity characteristics and to use them to determine the sodicity and salinity hazard within the aforementioned processes in the water of the Karha river basin area.

\section{Experimental}

Ground water samples from different seventeen wells of Karha river basin area are selected randomly and by considering the topography of the study area (Figure 2). 


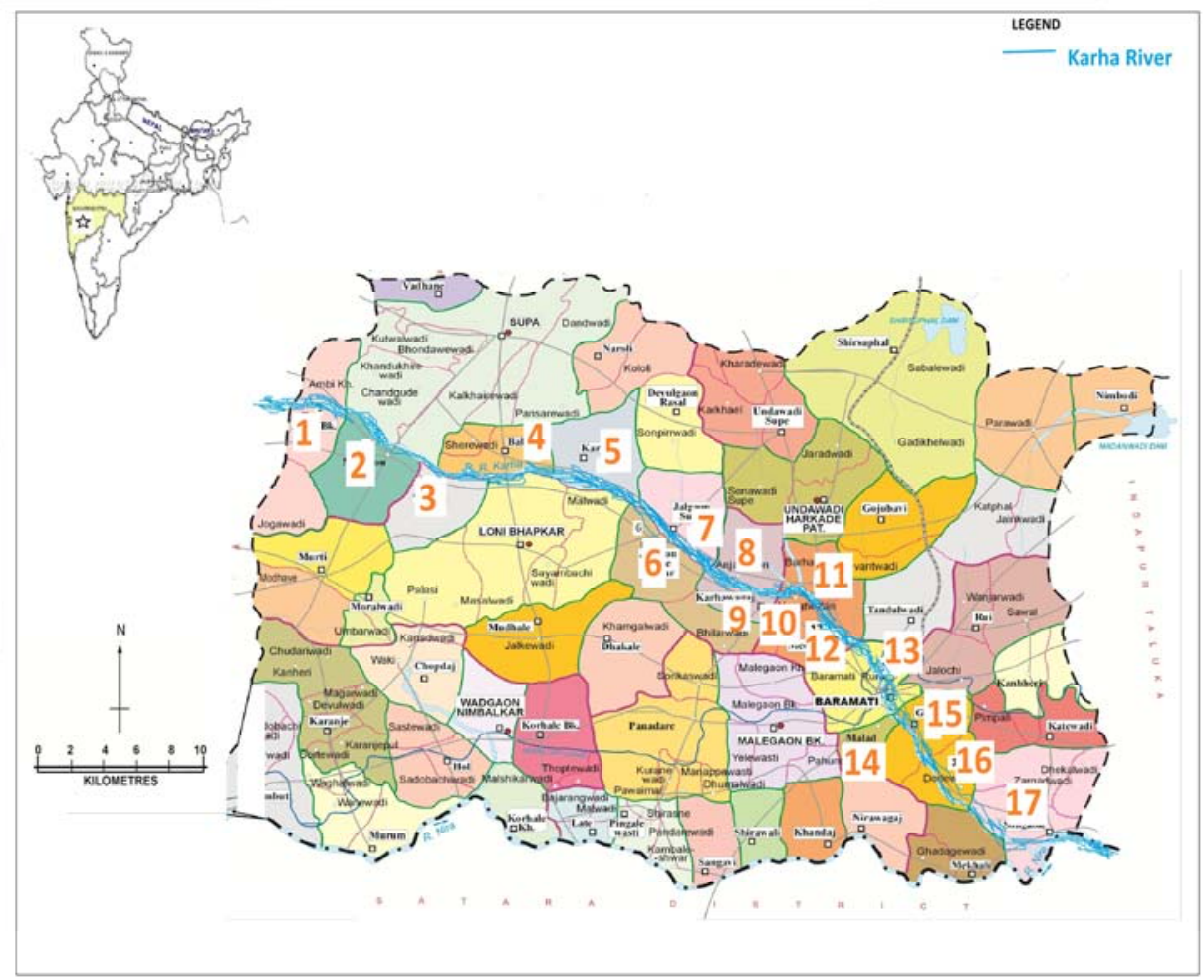

Figure 2. Location map of the study area

\section{Sample collection}

Water samples from the selected sites were collected in a good quality polyethylene bottle of one liter capacity during period September 2009 to May 2010 (winter and summer season respectively).

\section{Chemical analysis}

The concentration of salting ions was determined in groundwater samples. This concerns the anions: carbonates, bicarbonates, chlorides, sulphates and cations: calcium, magnesium, sodium, potassium. The $\mathrm{pH}$ and $\mathrm{EC}$ were measured and the SAR values calculated by using standard methods recommended by APHA ${ }^{4}$.

\section{Results and Discussion}

Chemical properties of ground water samples from different locations of karha river basin area are shown in Table 1 and $2 \mathrm{pH}$ value of water samples were varying from 6.75 to 8.6. Electrical conductivity (EC) of the groundwater is varying from 490 to $8920 \mu \mathrm{S} / \mathrm{cm}$ at $25^{\circ} \mathrm{C}$ in summer while 540 to $8650 \mu \mathrm{S} / \mathrm{cm}$ in winter season. The salinity hazard in the groundwater is considerable. $30 \%$ samples are with EC up to $750 \mu \mathrm{S} / \mathrm{cm}$ (minimum value $540 \mu \mathrm{S} / \mathrm{cm})$. In the rest of the area $(70 \%)$ salinity hazard is classified as high to very high with EC values up to $8650 \mu \mathrm{S} / \mathrm{cm}$ (Figure 3).

It is necessary to express the total concentration of dissolved salts in irrigation waters in terms of the electrical conductivity of water for diagnostic and classification purposes. 
Table 1. Water analysis data of Karha river basin area (post monsoon) winter 2009

\begin{tabular}{cccccccccccccc}
\hline S. & Sampling sites & \multicolumn{1}{c}{ pH } & \multicolumn{1}{c}{ Salinity } & TDS Sodium & RSC & SAR & $\mathrm{Ca}$ & $\mathrm{Mg}$ & $\mathrm{TH}$ & $\mathrm{Na}$ & $\mathrm{K}$ \\
\hline & & \multicolumn{1}{c}{$\mu \mathrm{SS} / \mathrm{cm}$} & $\mathrm{mg} / \mathrm{L}$ & $\%$ & $\mathrm{meq} / \mathrm{L}$ & & $\mathrm{mg} / \mathrm{L}$ & $\mathrm{mg} / \mathrm{L}$ & $\mathrm{mg} / \mathrm{L}$ & $\mathrm{mg} / \mathrm{L}$ & $\mathrm{mg} / \mathrm{L}$ \\
1 & Ambi & 7.71 & 540 & 346 & 23.81 & 2.7 & 0.76 & 14.03 & 34.05 & 175.2 & 25.3 & 0.8 \\
2 & Morgaon & 8.04 & 570 & 365 & 22.97 & 2.3 & 0.61 & 28.06 & 19.46 & 150.2 & 20.7 & 0.7 \\
3 & Tardoli & 8.5 & 1700 & 1088 & 55.40 & 0.4 & 2.56 & 30.06 & 19.46 & 155.2 & 89.24 & 0.9 \\
4 & Baburdi & 7.56 & 1650 & 1056 & 55.15 & 0.8 & 2.97 & 22.04 & 29.18 & 175.2 & 103.5 & 6.2 \\
5 & Karhati & 6.75 & 8650 & 5536 & 7.98 & & 0.71 & 116.23 & 391.55 & 1902.5 & 75.9 & 2.4 \\
6 & Jalgaon KP & 7.1 & 6400 & 4096 & 19.31 & & 1.70 & 242.48 & 268.74 & 1711.9 & 188.6 & 2.3 \\
7 & Jalgaon Supe & 7.16 & 3800 & 2432 & 27.48 & & 1.93 & 168.34 & 125.25 & 935.9 & 163.3 & 1.4 \\
8 & Anjangaon & 7.49 & 1200 & 768 & 24.54 & & 0.96 & 22.04 & 49.86 & 260.3 & 39.1 & 1.1 \\
9 & Karhawagaj & 7.25 & 1900 & 1216 & 29.49 & & 1.30 & 54.11 & 48.64 & 335.4 & 64.63 & 0.7 \\
10 & Nepatwalan & 7.88 & 7100 & 4544 & 33.43 & & 3.20 & 721.44 & 35.26 & 1945.9 & 450.8 & 5.2 \\
11 & Barnanpur & 7.58 & 1100 & 704 & 27.35 & 2.3 & 0.85 & 20.04 & 27.97 & 165.2 & 28.75 & 0.8 \\
12 & Medad & 8.38 & 7600 & 4864 & 33.58 & & 3.55 & 248.50 & 256.58 & 1676.8 & 391 & 4.6 \\
13 & Baramati & 7.3 & 1250 & 800 & 96.02 & 9.15 & 27.64 & 9.02 & 2.43 & 32.5 & 471.5 & 7.8 \\
14 & Malad & 8.11 & 1100 & 704 & 91.23 & 10.5 & 18.21 & 11.02 & 13.38 & 82.6 & 439.3 & 7.3 \\
15 & Gunawadi & 7.4 & 600 & 384 & 48.08 & 3.5 & 1.83 & 34.07 & 15.81 & 150.1 & 64.4 & 0.9 \\
16 & Dorlewadi & 8.19 & 650 & 416 & 66.24 & 0.85 & 5.02 & 9.02 & 37.70 & 177.7 & 163.3 & 2.7 \\
17 & Songaon & 7.76 & 810 & 518 & 56.03 & 4.75 & 2.49 & 17.03 & 19.46 & 122.6 & 73.6 & 2.4 \\
& Min & 6.75 & 540 & 347 & 7.98 & 0.4 & 0.61 & 9.02 & 2.43 & 32.5 & 20.7 & 0.7 \\
& Max & 8.5 & 8650 & 5536 & 96.02 & 10.5 & 27.64 & 721.44 & 391.6 & 1945.9 & 471.5 & 7.8 \\
\hline
\end{tabular}

Table 2. Water analysis data of Karha river basin area (pre monsoon) summer 2010

\begin{tabular}{cccccccccccc}
\hline S.No & Sampling sites & $\mathrm{pH}$ & Salinity & TDS & Sodium & $\mathrm{RSC}$ & $\mathrm{SAR}$ & $\mathrm{Ca}$ & $\mathrm{Mg}$ & $\mathrm{TH}$ & $\mathrm{Na}$ \\
\hline & & & $\mu \mathrm{S} / \mathrm{cm}$ & $\mathrm{mg} / \mathrm{L}$ & $\%$ & $\mathrm{meq} / \mathrm{L}$ & & $\mathrm{mg} / \mathrm{L}$ & $\mathrm{mg} / \mathrm{L}$ & $\mathrm{mg} / \mathrm{L}$ & $\mathrm{mg} / \mathrm{L}$ \\
1 & Ambi & 7.8 & 580 & 371 & 25.9 & 3.1 & 0.83 & 12.02 & 32.83 & 165.2 & 26.68 \\
2 & Morgaon & 8.12 & 580 & 371 & 23.3 & 2.4 & 0.64 & 30.06 & 20.67 & 160.2 & 22.54 \\
3 & Tardoli & 8.55 & 1800 & 1152 & 52.3 & 0.4 & 2.37 & 32.06 & 21.89 & 170.2 & 86.25 \\
4 & Baburdi & 7.7 & 1700 & 1088 & 56.3 & 0.7 & 3.07 & 20.04 & 30.40 & 175.2 & 105.8 \\
5 & Karhati & 6.8 & 8920 & 5709 & 7.7 & & 0.70 & 118.24 & 420.74 & 2027.7 & 77.97 \\
6 & Jalgaon KP & 7.3 & 6500 & 4160 & 15.9 & & 1.41 & 264.53 & 297.92 & 1887.1 & 163.8 \\
7 & Jalgaon Supe & 7.5 & 4000 & 2560 & 24.8 & & 1.75 & 172.34 & 138.62 & 1001.0 & 152 \\
8 & Anjangaon & 7.6 & 1150 & 736 & 22.3 & & 0.87 & 24.05 & 52.29 & 275.4 & 36.57 \\
9 & Karhawagaj & 7.65 & 1850 & 1184 & 27.4 & & 1.19 & 60.12 & 49.86 & 355.4 & 61.64 \\
10 & Nepatwalan & 7.85 & 7890 & 5056 & 33.70 & & 3.31 & 761.52 & 36.50 & 2051.1 & 478.4 \\
11 & Barnanpur & 7.7 & 800 & 512 & 25.4 & 2.5 & 0.78 & 18.04 & 29.18 & 165.2 & 25.99 \\
12 & Medad & 8.6 & 8050 & 5152 & 31.2 & & 3.28 & 262.52 & 271.17 & 1771.9 & 371.2 \\
13 & Baramati & 7.6 & 1350 & 864 & 96.1 & 9.6 & 26.62 & 10.02 & 1.22 & 30.0 & 454 \\
14 & Malad & 8.5 & 1150 & 736 & 91.2 & 11 & 17.61 & 12.02 & 12.16 & 80.1 & 424.8 \\
15 & Gunawadi & 7.7 & 490 & 314 & 45.4 & 3.6 & 1.69 & 36.07 & 17.02 & 160.1 & 61.64 \\
16 & Dorlewadi & 8.3 & 730 & 467 & 63.4 & 0.9 & 4.50 & 10.02 & 38.91 & 185.3 & 150 \\
17 & Songaon & 7.85 & 910 & 582 & 53.0 & 4.56 & 2.24 & 20.04 & 20.67 & 135.2 & 69.92 \\
& Min & 6.8 & 490 & 314 & 7.7 & 0.4 & 0.64 & 10.02 & 1.22 & 30.0 & 22.54 \\
& Max & 8.6 & 8920 & 5709 & 96.1 & 11 & 26.62 & 791.52 & 420.7 & 2051.1 & 478.4 \\
\hline
\end{tabular}




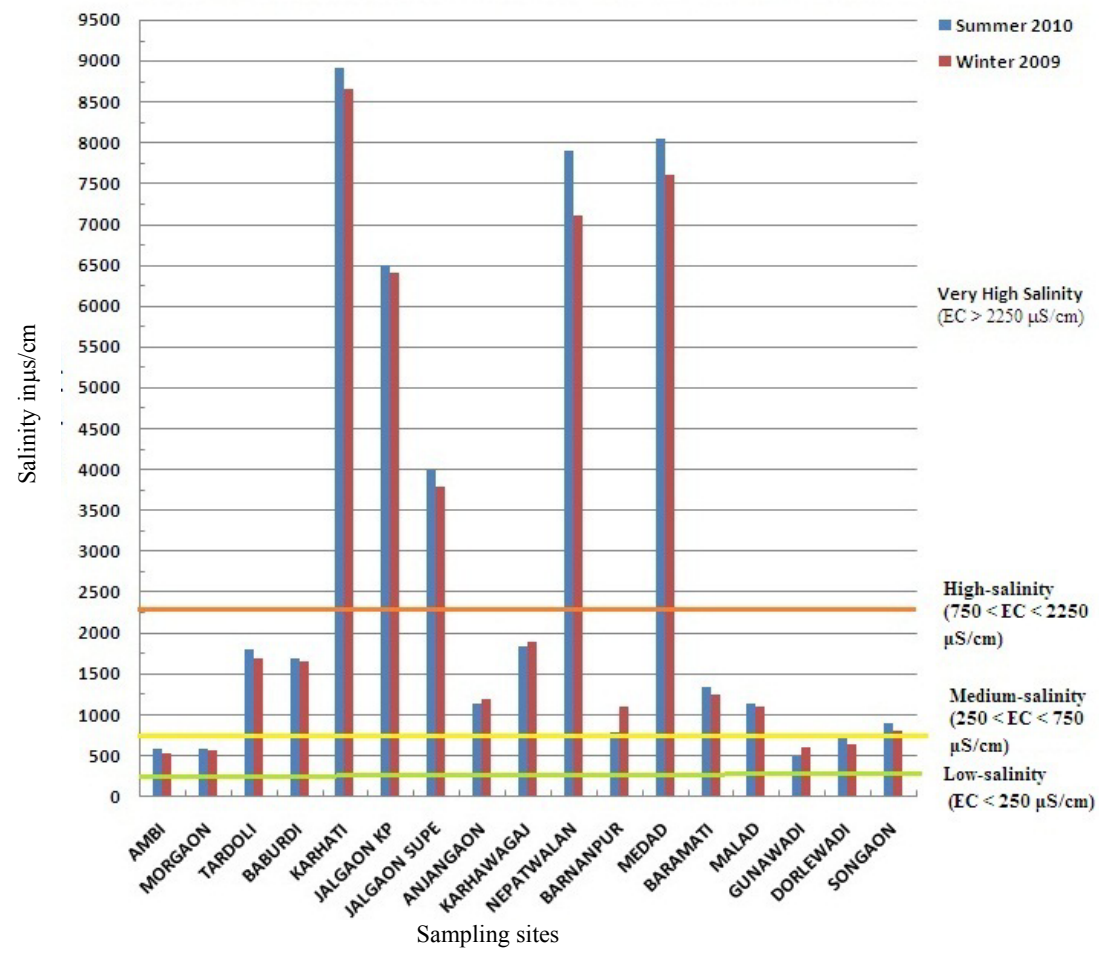

Figure 3. Salinity of ground water of Karha river basin area

Based on electrical conductivity, waters are classified into four classes according to Richards $^{3}$. The boundary values between the individual classes are 250,750 and $2250 \mu \mathrm{S} / \mathrm{cm}$. These limit values were determined on the basis of the relationship between the electrical conductivity of waters.

Low salinity water $(\mathrm{EC}<250 \mu \mathrm{S} / \mathrm{cm})$ can be used for irrigation of most crops on Probability that soil salinity will develop. Medium-salinity water $(250<\mathrm{EC}<750 \mu \mathrm{S} / \mathrm{cm})$ can be used if the soil is washed with a moderate amount of water. In most cases crops with a moderate salt tolerance can grow without applying special methods of salinity regulation.

High salinity water $(750<\mathrm{EC}<2250 \mu \mathrm{S} / \mathrm{cm})$ cannot be used on soils with restricted drainage. Special management of salinity regulation and choice of crops with good salt tolerance are required even for soils with adequate drainage.

Very high salinity water $(\mathrm{EC}>2250 \mu \mathrm{S} / \mathrm{cm})$ is not suitable for irrigation under ordinary conditions, but it can be used under very special circumstances. The soils must be permeable, drainage must be adequate, water must be applied in excessive amounts in order to ensure high soil leaching to be able to grow crops that are very salt tolerant.

The SAR value ranges from 0.61 to 27.64 in winter season while in summer season it ranges from 0.64 to 26.62 , indicating low, medium to high sodium salinization of the groundwater. In the winter season salinity of water slightly decreases, it may be due to dilution of water by rain.

The sodicity hazard is determined by absolute and relative cation concentrations. If the content of sodium is high, the sodicity hazard is high and vice versa. If calcium and magnesium 
are dominant, the hazard is low. The introduction of water quality classes with regard to the sodicity hazard is even more complicated than with regard to the salinity. The classification of irrigation water with respect to SAR is mainly based on the effect of exchangeable sodium on the physical condition of the soil. Sodium sensitive crops can be damaged due to the accumulation of sodium in plant tissues.

Low sodium water $(\mathrm{SAR}=0-10)$ can be used for irrigation on almost all soils with low risk of the emergence of harmful levels of exchangeable sodium. However, sodium sensitive crops can accumulate harmful concentrations of sodium.

Medium sodium water (SAR $=10-18)$ represents an obvious sodium hazard in fine textured soils having high cation-exchange capacity, especially in the case of low soil leaching if gypsum is not present. Such water can be used in coarse-grained soils or in organic soils with good permeability.

High sodium water (SAR $=18-26)$ can produce a harmful amount of exchangeable sodium, and will therefore require special soil management - good drainage, high soil leaching, and the addition of organic substances. Very high sodium water (SAR $>26$ ) is generally unsuitable for irrigation purposes.

\section{Conclusion}

Groundwater in the study area, Karha river basin area is classified as highly mineralized water with a high hazard of salinization of the subsurface environment. In the period from September 2009 to May 2010 the average EC concentrations in groundwater ranged from 490 to $8920 \mu \mathrm{S} / \mathrm{cm}$ at $25^{\circ}$. The plotted maps of the of salinity hazard (Figure 3) complement appropriately the knowledge of the hydrogeochemical composition of groundwater indicating, it can't be used on soils with restricted drainage and water is not suitable for irrigation under ordinary conditions but it can be used under very special circumstances. Seasonal fluctuations are observed in the water flow processes. The study of salinity serve as a reference basis when assessing alterations in its development in the period.

\section{Acknowledgment}

One of the author(s) (R. P. Dhok) is thankful to the Head, Department of Environmental Science, University of Pune for providing the necessary laboratory facilities.

\section{References}

1. WHO, WHO Guidelines for drinking-water quality First addendum to third edition, World Health Organisation, Volume 1.

2. Todd D K, Ground water Hydrology, John Willey \& Sons publishers, 2 Ed., New York, 1980.

3. Richards L.A, (Ed), Diagnosis and improvement of saline and alkali soils. US Laboratory Staff U.S., Dept Agric Handbook, 1954, 60.

4. APHA, Standard methods of analysis of water and wastewater (19th Ed), American Public Health Association, Washington D.C., 1985.

5. Ilangeswaran D, Kumar R and Kannan D, E- J Chem., 2009. 6(3), 898- 904.

6. Glen R. Bann and John B. Field, Dry land salinity in South East Australia: A localized surface water and soil degradation processes, Regolith-Consolidation and Dispersion of Idea, 2006.

7. Dahlhaus P G, Machewan R.J, Nathan E.L and Morand V.J, Aust J Earth Sci., 2000, 47, 3-11. 
8. $\quad$ Khodapanah L, Eur J Sci Res., 2009, 36(4), 543-553.

9. George R J and Frantom P W C, Preliminary groundwater and salinity investigations in the eastern wheatbelt 2, Merredin catchment, Resource Management Technical Report 89, Government of Western Austrelia, 1988.

10. Dale R K and Miller D C, Spatial and temporal patterns of salinity and temperature at an intertidal groundwater seepage, Estuarine, Coastal and Shelf Science, 2006, 1- 16

11. Esteban G. Jobbagy and Robert B. Jackson, Global Change Biology, 2004, 10, 1299-1312.

12. Ghassemi Fereioun, Jakeman A J and Thomas G A, Ground water, 1989, 27(3), 384392.

13. Gutteridge, Haskins and Davey, Murray valley salinity investigation, River Murray commission, Canberra V.1 the Report; v.2 Map; v.3 Summary. 1970.

14. Jacob W Kijne, How to manage salinity in Irrigated lands: A selective review with particular reference to irrigation in developing countries, International irrigation management institute, Colombo, Sri Lanka, 1998.

15. Ali M Subyani, J Environ., 2005, 60, 53-66. 


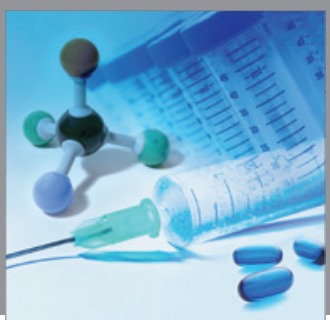

International Journal of

Medicinal Chemistry

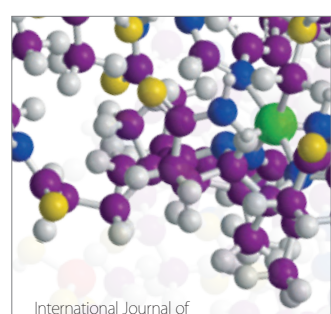

Carbohydrate Chemistry

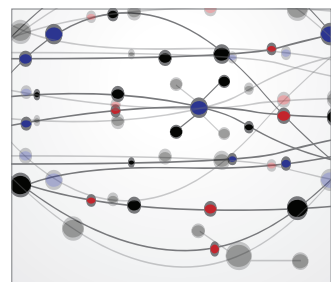

The Scientific World Journal
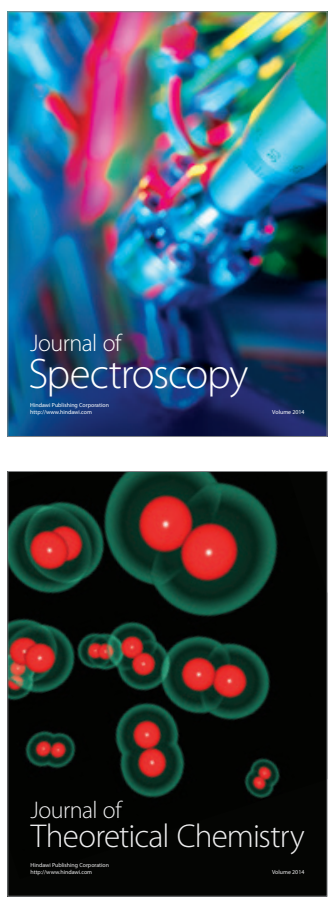
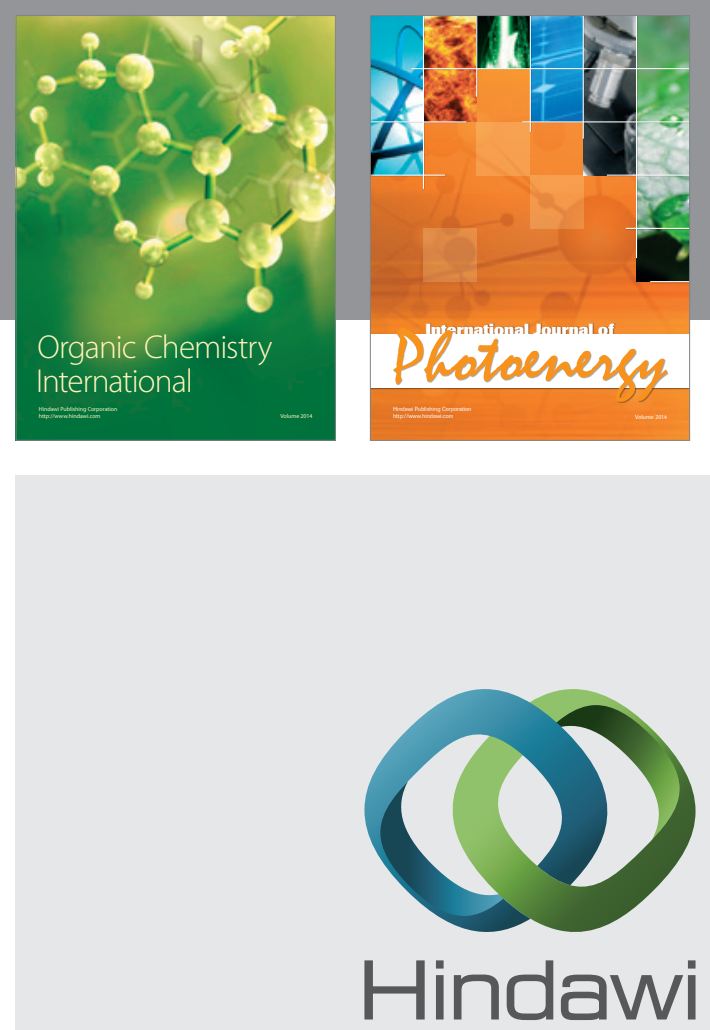

Submit your manuscripts at

http://www.hindawi.com
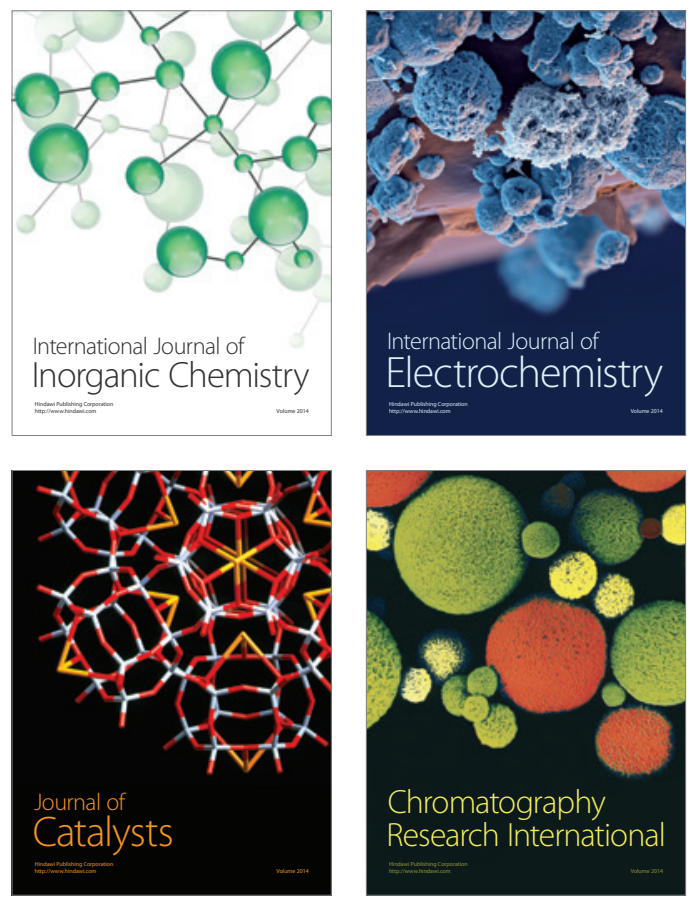
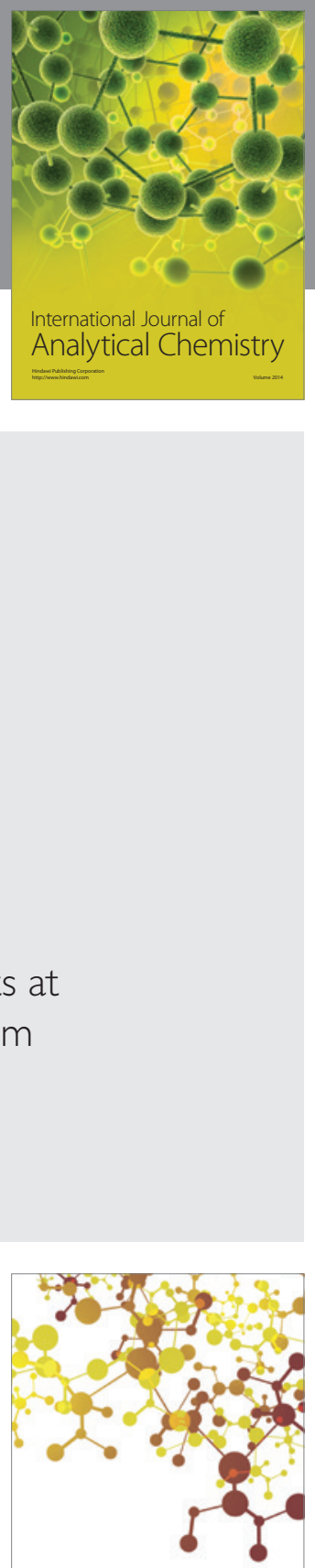

Journal of

Applied Chemistry
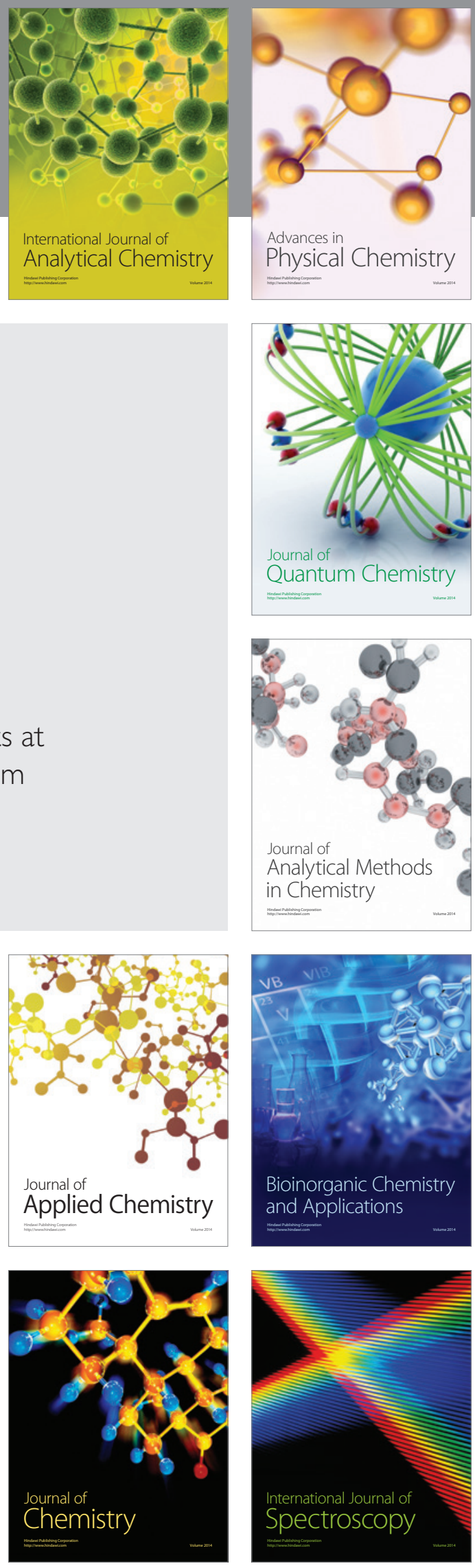